\title{
Spotlight on Challenges and Prospect of Directing in Nollywood: A Decade's Study (2006-2016)
}

Kingsley Chukwuemeka Anyira \& Divine Sheriff Uchenna Joe http://dx.doi./org/10.4314/ujah.v21i4.6

\begin{abstract}
The art of video film directing is all encompassing as the director deals with virtually all aspects of film production. This comes with herculean challenges that tend to mar the efforts of directors if not properly addressed. Film scholars cum critics have done a lot of work investing the challenges of the Nigerian Video Film industry with little or no effort to directly ascertain the peculiar challenges of each sector of the industry. To this effect, the paper seeks to source from the directors what these challenges have been over the decade in view and as well through the affected, proffer plausible suppositions as measure to ameliorate the identified challenges. In doing so, this paper adopts the view point that the director is the author of the film and thus engages the Survey research method wherein Personal interviews are employed as data collation tool and later analyzed with inferences made from the responses. Conclusively, it anchors on the directors' views of possible ways to improvelenhance the director's art in future productions.
\end{abstract}

\section{Introduction}

Today, the place of Nigerian video film as a means of entertainment, education and social enlightenment cannot be denied. Nigerian video films especially those produced in English have continued to enjoy considerable patronage in and beyond the shores of Nigeria. Along with this growing acceptance are questions as regards the challenges of video film production in Nigeria. Against this backdrop, this research intends to reflect from the directors' perspective on what 
these challenges are and also explore ways through which they can be alleviated; if possible totally expunged from the video film industry. The reason for this is that any film is a result of the director's effort, his point of view and his feeling which is why films are firstly presented by the name of their director(s), and not the producers or the stars (Sedat Cereci, 1). In some cases, efforts have been made to unravel these challenges as a whole without much work done to identify these challenges from the specific views of select professionals who make up Nollywood as it directly affects them. In particular, this research intends to focus on drawing out to the full glare of both video film practitioners and film scholars, what these problems are; based on the perspective of the film director(s).

\section{Who is a Film Director?}

The director, whether he explicitly controls all the subordinate work of a film or merely creates a certain context through his very presence, is the only participant in a film's creation whose moment of self-expression is wide enough and thus whose artistic vision may come to characterize the film as a whole. The director's very role in the film making process forces him to attend- explicitly or implicitly to the entire film (Filmmakers). He shapes it and directs its creativity. Ken Dancyger submits that:

In each case, the consciousness of the director's idea is where progress begins. The competent director conveys a singular attitude about the script, be it romantic, violent, or victorious. The good director conveys a more complex, layered vision of the narrative. The great director transforms the narrative into something surprising and revelatory. Each of these options exists. Only the ambition of the director can elevate the audience's experience (13).

By the same token Sedat, Cereci observes that: 
Director is the person responsible for the creative aspects, both interpretative and technical, of a motion picture production in a film. In addition to orchestrating action in front of the camera and guiding acting and dialogue, film director controls camera position and movement, sound, lighting and all other ingredients that contribute to the final look of a motion picture (3).

Contributing the roles of director in film making, Kim Jong Li in The Cinema and Directing states that, "The director is the commander of the creative group. He should have the overall responsibility for artistic creation, production organization and ideological education and guide all the members of the creative team in film- making" (2). This is to imply that the role of the director in film-making is unitary and all encompassing in nature. But the way he plays this role can be determined by the society in which he/she is domicile. On this, Kim further notes that:

The director in the socialist system of film-making is fundamentally different from the "director" in a capitalist society... In the capitalist system of film-making the director is called "director" but, in fact, he is an agent of the tycoons of the film-making industry whereas in the socialist system of film-making the director is not a mere worker who makes films but the commander, the chief who assumes full responsibility for everything ranging from the film itself to the political and ideological life of those who take part in filmmaking (2-3).

Drawing meaning from the above statement, the society is a determinant factor in directorial roles, artistic expression and the end product in film production which also implies that as society differs from another so are the challenges video film directors are faced with. 
A study into what a contractual agreement between a film director and producer reveals that the rights and job descriptions of a film director include many but to mention a few as: monitoring and approval of the final version of the manuscript; appointing artistically executive persons, casting and choice of filming locations together with the producer; approving the production plan, production schedule, budget and marketing plan together with the producer; monitoring of the post-production works; image and sound editing, music selection, mixing, colour specification, monitoring of the image post-processing and approval of the final film form; the director shall decide on the final film form of the film within the frames set by the agreement and in accordance with the Producer's instruction (Film Director Agreement, 2-4). A careful view of the all aforementioned brings to the fore the thought of what challenges he/she could face to complete the task of film directing successfully.

Because of all the work that goes into his job, a film director gets most of the credit for his finished piece of work. This is largely because he is so intimately involved in all aspects of the film's development (Fransworth). Based on this, the director's opinion could be regarded to represent to a large extent, all the facets of film production and the inherent challenges there in.

Regarding who can be a director in terms of gender in whatever clime or society, the answer is that the both sexes can be directors but it remains a fact that there are more male directors than the females. This is not only in Nollywood but also evident in other video film industries around the world. A study on gender disparity among film directors in the United Kingdom film industry reveals that: "Just $13.6 \%$ of working film directors over the last decade were women. Only $14.0 \%$ of UK films had at least one female director. UK films are over six times more like to be directed by a man that a woman" (Follows, Kreager and Gomes, 14). Furthermore, Follows, Kreager and Gomes noted that the reason for this gender disparity 
were traced to more of Systematic issues than unconscious individual bias listing these principal four systematic issues as:

There is no effective regulatory system to police or enforce gender equality. The pervasive nature of uncertainty which creates a climate of insecurity, leading to illogical and ritualistic behaviours resulting in the industry operating based on preconceived motions of the archetypal director, rather than on the their individual abilities and talents. The permanent short-termism in the film industry. The vicious cycle of individual bias leads to systematic issues and vice versa, so the system is self sustaining (79).

These systematic issues raised above tend to be the order of the day in Nollywood as there are only but a few notable female directors in the industry and thus limits the voice of the female folks in what could be the challenges of film directing.

Whether male or female, the training of a film director which determines his/her philosophical approach in cinematic expression to a large extent contributes to the challenges that may be encountered in the production of a film. Attesting to this, Rosalind Nugent-Williams in her work Australian Film Directors and Film Performance notes that:

In Crombie's case, it appears that his original training in theatre, where he was steeped in the craft of acting, has indeed influenced his approach as a director- he is actor focused and his method involves collaboration with actors to develop character. By his own admission, he uses Stanislavskian method, which he learned at NIDA. In at least part of his key work with actors and accordingly his NIDA training has had a marked influence on his later work (59).

Considering the enormous demand on Nollywood as a result of the populous nature of Nigeria, the industry has over the years witnessed 
a rise in the number of directors who have contributed in one way of the order to the ever increasing number of film productions that Nollywood has recorded in recent years. Helena Barnard and Krista Toumi observed that "its annual output is estimated at between 500 and 1,000 films- with The Economists estimating it at as much as 2,000 films" (14). It is against this background that this research work intends to source information directly from the directors in regards to the challenges of video film production in Nollywood.

\section{Why Study the Director's Art?}

Every human endeavour is faced with challenges; the video film industry is not exempted from challenges which if surmounted, will contribute to its development and growth. There have been calls in recent times from within and outside the Nigerian video film industry popularly referred as Nollywood for the challenges of the sector to be addressed by appropriate authorities. These calls have revealed that almost every movie production in Nigeria is problematic and has been affirmed by practitioners themselves. As a result of this, the Nigerian film maker is subjected to many constraints which aim at to stifling and emasculating the great role he could play in reflecting and expressing the efforts and endeavours of the people. These revelations therefore necessitate an investigation into what makes almost every movie production in Nigeria problematic. It will consider the remote causes, the prevalence of these problems and mitigation measures. To this effect this research will try to proffer concrete answers to the following research questions: Are Nigerian video film directors allowed to fully take charge of productions? What are the artistic and professional constraints of directing video film productions in Nigeria? Are there sufficient and readily available financial resources for the directors to work with? Are there other external factors outside the video film industry that pose a challenge to film production in Nigeria? Are there measures that are being put in place to ameliorate 
or mitigate these challenges that are faced by Nigerian video film directors? How can video film production in Nigeria be improved upon to enable the directors do their job without hitches?

It is intended that by the conclusion of this research, it will be able to unravel the prevalent challenges of Nigerian video film production from the experiences of the film directors whose role in the industry cannot be underestimated. The findings of this research are intended to serve as possible template for addressing the need of film production in Nigeria starting with that of film directors. It will also serve as a reference material for future researches into the challenges of film production in Nollywood from the perspective of other film production personnel not undertaken by this study. Thus, a selected number of film directors who are recognized members of the Directors' Guild of Nigeria (DGN) and have been practicing in the decade in review.

\section{Theoretical Framework}

Based on the foregoing, the theoretical frame work hinges on film directing and Auteurism. Thompson, Kristin and David Bordwell point that:

Auteurism sensitizes viewers to narrative experiments that expressed a director vision of life. It also prepared viewers to interpret stylistic patterns as the filmmaker's personal comment on the action. Auteur critics were especially alert for ambiguities that could be interpreted as the director's reflection on a subject or theme (382).

As deduced from the above, the director's ability to make the audience see his personal imprint on a given production different from what may be obtainable in normal situation marks him out as an auteur. Robert Stam in Film Theory: An Introduction notes that: 
Auteurism took a different turn when it was introduced to the United States by Andrew Sarris in his "Notes on the Auteur Theory in 1962 "... The critics must therefore be alert to tensions between the directorial personality and the materials with which the director works ... Sarris proposed three criteria for recognizing an auteur: (1) technical competence;

(2) distinguishable personality: and (3) interior meaning arising from tension between personality and material (89).

The first stated view of auteurism implies that initially, auteurism was conceived to enable critics engage only the directors' work in relation to their ability to make stylistic statements without regarding the process and encumbrances that are encountered by these directors in the process of doing so. Later on with the expansion of knowledge through further research as indicated in Stam's contribution, it became necessary for critics to look beyond the director's vision of life as expressed in films only but also consider what transpires between the director and the resources available to him (both human and material resources) which in one way or the other may have contributed to the meaning he gives to a film.

Contributing towards another view of auteurism with emphasis on the acknowledgement of external factors that affect film production and invariably the director's work, Erin Hill-Parks reveals that:

Although auteur ideology has its roots in structural and modern theories, it can be evolved and applied to contemporary film studies using post-structural and postmodern ideas. Moving thinking about the auteur into postmodern concerns allows for both the abstraction of an author, but the acknowledgement that a physical individual exists who is also influenced by social and cultural factors. Culture and in this case film specifically, needs to be considered through the conditions of production... (39). 
This opinion indicates a swift shift from the founding ideologies of auteurism introducing a fresh understanding of the theory in tandem with changing realities of modern filmmaking. Furthering this shift, Thomas Dorey submits that:

Contemporary auteurists scholars such as Brian Michael Goss in his 2014 analysis of Steven Soderbergh's The Limey have recourse to a modified version of auteurism which moves far from Sarris' subjectivity, instead acknowledging the influence and importance of other factors of production external to the director or writer while focusing on the auteur in order to produce a cohesive study (3).

Hill- Park and Dorey's trajectory of auteurism moves criticism of the auteur's output not only about his personal stylistic imprint on the production but to encompass the entirety of all factors that contribute to the final outcome of such production as it directly or indirectly affects the director. Based on these, this study on the challenges and prospects of Nigerian video film directors will be anchored on the auteuristic theoretical paradigm.

\section{Methodology}

To determine issues that are inherent in this study, the Survey research Methodology will be adopted. Dealing with the Survey method, personal interview will be adopted as the investigative tool. Emeka Nwabueze opines that:

Personal interview is one of the most effective means of obtaining pertinent information in survey research. This is because personal interview accords the researcher the opportunity of face-to-face interaction with the respondent. He can ask follow-up questions, direct the destination of the interview to significant issues and seek clarification where necessary (66). 
This research method is necessitated by the nature of the research problem and the objective of the study. Therefore, the researcher will engage selected Nigerian video film directors with requisite experience on incisive interviews that are designed to decipher the challenges and prospects of video film production that truly depict the views of the directors. These interviews will be conducted using a validated questionnaire and data collated will serve as basis for analysis on the subject.

\section{Directorial Persona of the selected Video Film Directors}

To authenticate and validate the information on what are the challenges of video film directors in the decade in review, this study set criteria for the selection of the video film directors who are to serve as respondents to the research questionnaire. These criteria include: Membership of the Directors Guild of Nigeria (DGN); Practice of not less than ten years with not less than twenty video film titles; Awards winning and nominations; and Participation at renowned film festivals either locally or abroad as well as working experience with A-List artists within and beyond the shore of Nigeria. Based on this premise, the selected film directors are as follows.

\section{Okey Ezubelu Okoh}

We shall begin with Okey Ezubelu Okoh a Nigerian video film director and screen writer based in Asaba, Delta state, South-South Nigeria. He debuted in 2003 as a video film director after under studying prominent film directors in the persons of Ndubuisi Okoh and Chika Onu. He is a registered member of the Directors Guild of Nigeria (DGN). Among the titles directed by him are Will of God, Weeping Angel and Mirror of Beauty which got nominations in seven (7) award categories at the African Movie Academy Awards and won the Best Music category in 2008. 


\section{Emmanuel Eyaba}

Emmanuel Eyaba, a member of the Directors Guild of Nigeria (DGN) is based in the Abuja, the Federal Capital Territory of Nigeria. He is a video film director trained in Theatre and Media Arts at the University of Calabar and began directing professionally in 2006 after understudying another video film directing colossus Teco Benson. Since then, he has directed over twenty (20) video films among which is The Frontiers, an action series for the Nigerian Custom Service. He then proceeded to Colorado Film School in 2014 for a professional course in film directing. His film, Millimeters was nominated for the best short film at the 2009 ION film festival in Port-Harcourt, Nigeria and later another, Spycing was nominated for best feature film at Zulu African Film and Academy Awards (ZAFAA) in 2012.He is currently working on a movie on climate change for Green Economics Institute and another on early marriage for the African Union.

\section{Chima Okereke}

Chima Okereke is an Imo state University and University of Ibadan trained practicing Nigerian video film director and screen writer based in Lagos state, South-West Nigeria. He later attended the United Nations/EMPRETEC Entrepreneurship Training studies at the Colorado Film School, USA. He has been directing professionally for more than fourteen (14) years and is a frontline member of the Directors Guild of Nigeria (DGN) where he was once the Director of Finance and National Secretary. He is at present a resource person / member of faculty of International Film Broadcasting Academy (IFBA), Lagos. Some of the video films directed by him have been screen at the Abuja International Film Festival. Video films directed by Chima Okereke include Beautiful Strangers, And She Came, Uwa Umunwanyi, Patito's Aunty, Hidden Scar, etc. 


\section{Amaechi Ukeje}

Amaechi Ukeje is a Nigerian video film director based in Enugu, Enugu state, South-East Nigeria. He is a member of the Directors Guild of Nigeria who understudied Afam Okereke and Andy Chukwu and debuted film directing in 2006 and has directed over thirty (30) movie titles which includes The Judas Game, Terrors and Tears, Scent of a Woman, Twinlight Sisters and others. He has worked with many of the most sought after actors in the Nigerian film industry and beyond including Mercy Johnson, Ali Nuhu, Chika Ike and Majid Michael from Ghana.

\section{Challenges of Directing in Nigerian Video Film Productions - Inability to Take Full Charge of Productions}

The responses indicate that in the actual practice of filmmaking the director is supposed to be in charge of productions but the case in Nigeria differs from one production to another. For Eyaba, it is a yes while Ezubelu, Ukeje and Okereke are of the opinion that it is rather circumstantial and conditional for directors to take full charge of productions in Nigeria. The role of Nigerian video film directors are challenged by over exuberant marketers, producers and executives producers who in some cases interfere with casting and determination of crew members. Their success in this interference as provided by the respondents is determined by the individual and professional makeup of the director in charge of a particular production.

\section{- Artistic and Professional Constraints:}

All the directors in response to this touched on inadequate financing. However, Okereke is of the opinion that where equipments are available, there is limited number of professionals who are acquitted with the knowledge of their usage and operation thereby making such equipment inapplicable to productions. $\mathrm{He}$ adds that another constraint is the lack of self-development by directors which inhibits 
their professional practice, ability to keep up with international best practices and reach. Finally, Eyaba notes that inadequate planning is bane on both artistic and professional output of the entire industry.

\section{- Unavailability of Financial Resources for Directors}

These directors emphatically state that the availability of finance for directors to work with is not assured. Where and when there are channels to source funds, the conditions attached are stringent and difficult thereby discouraging them from undertaking such. This lack of ready finance emanated from the fear by would-be investors who are not sure of how they would recoup their investment because of the disorganized structure of the industry in Nigeria.

\section{- External Factors}

The external factors challenging video film directing and production in Nigeria as provided by the directors can be itemized to include lack of accessibility to facilities like government and exclusive public centres considered as sacrosanct which inhibits the directors from effectively recreating reality. In addition, piracy is pointed out as another factor coupled with non-up-to-date legislation that ensures standards and business growth in Nigeria. There is also a mention of inadequate of limited number of cinemas in ratio to large audience or viewer base of the industry in the country. Worthy of note is that of breach of ethics and contracts that prevails as a result of lack of statutory authority of guilds to ensure standards which imply that the guilds are lack constitutional powers to this effect. Power, which is a challenge to almost every sector in Nigeria, also poses a challenge to video film directing and production as revealed by Eyaba. 


\section{Prospects of Directing Video Film Productions in Nigeria}

- Measures to Ameliorate/Mitigate Challenges Faced by Nigerian Video Film Directors

Ezubelu, Ukeje and Okereke all pointed to the Motion Picture Practitioners Council of Nigeria (MOPPICON) bill. According to Ezubelu, this bill is meant to be passed to the national assembly for deliberation and then passed into law. It is like a regulator that will regulate movie practice in Nigeria therefore making it impossible for anybody to come into the industry to do whatever they want without anyone asking questions. He believes when MOPPICON comes into being, it will help checkmate irregularities in the industry. Ukeje notes that MOPPICON which is an initiative that seeks to create an umbrella body regulating all practitioners in Nollywood, the bill even at its preliminary stages of at the National Assembly, is already generating heat because most in Nollywood are non-conformers. Despite this, He expresses hope that if MOPPICON should be passed, it would mean that non-members of the different guilds in the industry for example, Directors Guild of Nigeria would be prohibited by law to direct a movie or motion picture in Nigeria just like what is obtainable in law practice with the Nigerian Bar Association (NBA). If you are not a member of the NBA, you cannot represent somebody in court. Aside MOPPICON, Ukeje adds that individual directors do travel abroad to reputable film schools all over the world for training coupled with added courses locally at Nigerian Film Institute and other places. Furthermore Ukeje notes that as a body, DGN periodically organizes training workshops for its members to enhance their professionalism unlike in other groups who are unstable as a result leadership squabble and other things which has not enabled them to look do same as DGN. The body also encourages its members to offer professional assistances to each other on and off the set without charges. 
However, Eyaba revisits the assistance with capacity funds, production fund and equal distribution of these funds which government tried to do through Project Art stressing its sustenance as it will change the face of filmmaking.

\section{- Suggestions on Professionalization of Video Film Directing in Nigeria}

The opinions of the resources persons on how directing in Nigerian video films can be enhanced reveals that reorientation of individuals that is, investors, markers and executive producers that infringe on the roles of a director ranks high. However, this does not leave out the directors themselves from the call for reorientation. This necessitated by the fact that some directors are impediments to themselves and their colleagues as a result of inadequate knowledge on what the responsibilities of a director are on and off the set. Based on the foregoing, the directors emphasized on re-orientation, the emphasis on training and re-training with provision of better structures that will enhance the directors' creativity must not be dealt with a wave of the hand. In addition to this, provision of facilities such as film village as done in other climes and fully committed involvement of government as a reward to the sector for creating a unique Nigerian brand that is recognized globally is required.

\section{Conclusion}

It has been established by the data collected and analyzed in this study that the director in Nigerian video film industry has been faced with challenges in the decade in review (2006-2016). These challenges as provided by the directors themselves range from undue interferences from investors, marketers and executive producers whom they point at as not allowing them to effectively play their role in the process of filmmaking thereby hampering their creativity and productivity. Furthermore, they revealed that lack of finance as a result of 
negligence by government and other corporate institutions, inadequate distribution channels that does not ensure returns of investment thereby discouraging investors, improper orientation of artists. Others are unavailability of up-to-date filmmaking equipment, limited number of professionals who are acquainted with the knowledge of the usage of these equipment when and where they are available, lack of self-development by video film director in order to be in tune with international best practices, inadequate planning by almost every practitioner in the industry, last but not the least include lack of an organized structure indicated by the absence of a legislation guiding the practice of film in the country, inaccessibility of exclusive facilities, high rate of piracy, breach of ethics and contracts, inadequate number of cinemas and poor power supply within the country. From the foregoing deducing suggestions on how their art can be improved upon for greater creativity and qualitative output is imminent. These include the enactment of the Motion Picture Practitioners Council of Nigeria (MOPPICON) bill into law, continuation of the Project Art which was initiated by the Goodluck Jonathan administration, improved government and private sector involvement, and provision of better structures for the directors and industry at large.

\section{Kingsley Chukwuemeka Anyira}

Department of Theatre Arts.

College of Education, Agbor, Delta State \&

\section{Divine Sheriff Uchenna Joe}

Department of Theatre Arts \& Film Studies

Imo State University,

Owerri, Imo State 


\section{Works Cited}

Barnard, Helena, and Krista Tuomi. "How Demand Sophistication (De-) Limits Economic Upgrading: Comparing the Film Industries of South Africa and Nigeria (Nollywood)". Industry and Innovation 10.1080 (2008): n.pag. Print.

Cereci, Sedat. "Role of Director's Philosophical Approach in Cinematographic Expression". Arts and Sciences Journal 55 (2012): 1-6. Print.

Dancyger, Ken. The Director's Idea. The Path to Great Directing. Oxford: Elsevier: 2006. Print.

Dorey, Thomas. "Wes Anderson: Contemporary Auteurism and Digital Technology". Diss. Ontario: Carleton University Ottawa, 2009.

Follows, Stephens, Alexis Kreager and Eleanor Gomes. Cut out of the Picture. A Study of Gender Inequality amongst Film Directors in the UK Film Industry. London: Directors UK, 2016.

Fransworth, Billings. "The Importance of a Film Director.". Ezine Articles. 7 Aug. 2009. Web. 2 Mar. 2016.

Hill-Parks, Erin E. "Discourse of Cinematic Culture and the Hollywood Director: The Development of Christopher Nolan's Auteur Persona". Diss. Newcastle: Newcastle University, 2010.

Lacey, Nick. Intoduction to Film. New York: Palgrave Macmillan, 2005. Print.

Janstova, Patricie. "Empirical Testing of Auteur Theory via Content Analysis. A Study of Jane Campion Films". Diss. Ohio: Cleveland State University, 2003.

“Job: Film Director- How Directors Work”. FilmMakers. N.p.,1999. Web. 4 Mar. 2016. <http://

www.filmmakers.com/Job: Film director-How Directors work/>.

Kim, Jong Il. The Cinema and Directing. Pyongyang: Foreign Language Publishing House, 1987. Print. 
Nwabueze, Emeka. Research Methods An Integrated Approach. $2^{\text {nd }}$ ed. Enugu: ABIC Books, 2013. Print.

Nugent-Williams, Rosalind. "How do our Directors Work Actors on Performance and What is the Dominant Approach to Directing Actors in Australian film?" Diss. Brisbane: Queensland University of Technology, 2004.

Paul, Watson. "Approaches to Cinematic Authorship". Introduction to Film Studies. Ed. Jill Nelmes. New York: Routledge, 2006. 90-108. Print.

Stam, Robert. Film Theory. An Introduction. New York: Blackwell Publishers, n.d. Print.

"The Challenges of Making Historical Film in Nollywood". School of Media and Communication- Pan American University. 2014. Web. 4 Mar. 2016.

Thompson, Kristin and David Bordwell. Film History. An Introduction. $3^{\text {rd }}$ ed. New York: McGraw-Hill Companies, 2010. Print.

\section{Interviews:}

Eyaba, Emmanuel. Personal Interview. 10 Oct. 2016.

Okereke, Chima. Personal Interview. 8 Sept. 2016.

Okoh, Okey E. Personal Interview. 1 Nov. 2016.

Ukeje, Amaechi. Personal Interview. 6 Sept.2016. 